\title{
REVIED The politics of staying behind the frontline of
}

\section{coronavirus [version 2; peer review: 2 approved]}

\section{Stephanie Davies}

Department of Psychosocial Studies, Birkbeck University of London, London, WC1B 5DT, UK

V2 First published: 10 Jun 2020, 5:131

https://doi.org/10.12688/wellcomeopenres.15964.1

Latest published: 02 Sep 2020, 5:131

https://doi.org/10.12688/wellcomeopenres.15964.2

\section{Abstract}

Intended as a contribution to the Waiting in Pandemic Times project Collection in response to COVID-19, this short theoretical paper views the coronavirus crisis in terms of its unpredictable effects on the interior life of the National Health Service (NHS) workforce. Written immediately following the suspension (due to the pandemic) of an ethnographic investigation of waiting in a general practice in London, it tracks the first signs that working definitions of time would struggle to survive the onset of a temporality of acute crisis in the NHS. The paper considers what it might mean for healthcare practitioners at this particular moment in the NHS's history to be living through an experience of 'the ordinary' breaking down. It also follows hints of new temporal modes of care appearing during this same period when one kind of crisis in the NHS has been put on hold, and another (the crisis of coronavirus) is just getting underway.

\section{Keywords}

COVID-19 pandemic, NHS culture, ethnography of care, Dejours, temporality and healthcare

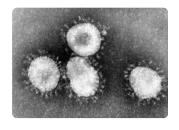

This article is included in the Coronavirus

(COVID-19) collection.



This article is included in the Waiting and Care

in Pandemic Times collection.

Open Peer Review
Approval Status
version 2
(revision)
02 Sep 2020
version 1
10 Jun 2020
1. Trish Gre...............................................................
Oxford, UK
2. Sara M. Bergstresser (iD), Columbia
University, New York, USA
Any reports and responses or comments on the
article can be found at the end of the article.


Corresponding author: Stephanie Davies (sdavie16@mail.bbk.ac.uk)

Author roles: Davies S: Conceptualization, Writing - Original Draft Preparation

Competing interests: No competing interests were disclosed.

Grant information: Waiting Times is funded by the Wellcome Trust [205400].

The funders had no role in study design, data collection and analysis, decision to publish, or preparation of the manuscript.

Copyright: (c) 2020 Davies S. This is an open access article distributed under the terms of the Creative Commons Attribution License, which permits unrestricted use, distribution, and reproduction in any medium, provided the original work is properly cited.

How to cite this article: Davies S. The politics of staying behind the frontline of coronavirus [version 2; peer review: $\mathbf{2}$ approved] Wellcome Open Research 2020, 5:131 https://doi.org/10.12688/wellcomeopenres.15964.2

First published: 10 Jun 2020, 5:131 https://doi.org/10.12688/wellcomeopenres.15964.1 


\section{REVISED Amendments from Version 1}

Included in the paper is now a brief outline of my original investigation into waiting in general practice. The theoretical nature of the paper and its tangential relation to ethnographic observation is made more explicit. There is also a short passage introducing Paul Ricoeur who was a philosopher of time and action, making brief reference to his theory of the Promise.

Any further responses from the reviewers can be found at the end of the article

During a crisis on the scale of coronavirus, the invisible forces holding an institution's 'time' in place (Hammer, 2011) ${ }^{1}$ can seem to collapse, as they suddenly lose their power to regulate the institution's everyday life in the drastically altered situation. I was a researcher undertaking an investigation of waiting in a London general practice when I heard the news that the virus, seemingly so far away, had arrived, having entered literally through the front door. In the hours that followed the first suspected case, all thoughts were immediately drawn towards the virus, siphoned off from wherever they had happened to be only an hour before and, after having being relied upon for so long to replenish everyday life in the surgery with its essential quality of 'everydayness', many long established orderings of time and space - meeting times, consultation times, waiting room times, lunch-time, opening and closing times, patterns of movement through the building - were reduced to just the remainders of what was left over after the coronavirus had taken hold. So too were the ordinary patterns of behaviour and identification that had belonged to them; of employees knowing how to compose themselves as those who 'work for the National Health Service (NHS)'. Through rapid modes of improvisation and with an intensity that might have come from the combined energies of so many people all furiously channelling what was going on around them, they very quickly began to reconstitute themselves as those who work for a different kind of NHS, one still in the process of being formed out of a time of national emergency. This all seemed to take place over the course of a single morning, just a day after the first suspected case of coronavirus had entered the building.

The original research questions I had just then begun to investigate had sought to grasp waiting in healthcare in its everyday aspect — as a circumstance so taken for granted that many of its lesser known functions for general practice tended to be overlooked. Through observations of patient consultations and other sites of decision-making, I had been watching for the details of how waiting happens in these settings, whether out of necessity, by accident or by design. I wanted to know what people 'did' with waiting: how they used or consumed it; how waiting was 'made' or engineered out of the things available and at hand; what it 'looked like' to wait here, and how waiting was being made 'readable' or 'unreadable'

\footnotetext{
${ }^{1}$ The time 'kept in place' refers to the local arrangements for inferring time from structures imposed or engendered; the 'specific temporal economy' of an institution (Hammer, 2011, p. 26)
}

for the NHS or for this particular organisation. When the virus had struck without warning just as the observations had started, the structures that had supported everyday forms of waiting appeared to fall away, carrying my original research questions along with them. In place of my old investigation of waiting at its most ordinary in general practice, the new questions arising had corresponded to an altered reality - one not at all orderable by the standards of the everyday.

The orderings of time that are usually seen to be of utmost importance for the future - recording, inspecting, reviewing for instance - are suddenly made to appear extremely relative alongside the infinitely more pressing and immediate demands of the present: the saving of life, the protecting of one's own life, and the need to survive the crisis. At such a moment, a person might get caught up in the end of one set of working conceptions of time, before another has even begun to circulate. Yet, for those healthcare workers who might now be experiencing something like this in their own NHS workplaces, the failure of the ordinary to assimilate the fears, risks and demands connected with an unknown virus, is an event that they have had no choice but to find some way of working through. So how are they keeping time in such a crisis? (Catty, 2020, Waiting in Pandemic Times).

The interior life of the workplace is said by Christophe Dejours to hardly ever be allowed to show itself, except in very rare situations (Dejours, 2007). The hiddenness of its invisible inner workings and affective economies is believed to be partly due to a lack of interest by the public whose currency is mainly that of the name or brand of the organisation (the part that faces outwards), but also because the workers themselves are thought to be complicit in secreting the inner-functioning of their own institution with whom they are required, at least in part, to identify. At this time of great public interest in watching the collision of coronavirus with healthcare systems all over the world, the growing intensity of collective identification with the aims of the NHS and its projection onto the workforce, could mean that the privately felt realities for NHS staff, of becoming part of a temporality of crisis, are even more likely than usual to remain hidden from view.

On the surface, the crisis appears to have prompted new modes of agency that have begun to emerge in NHS settings hinting at a shift in the perspectives of its workforce. This is discernible in the celebration of activities and practices, that may not always have been considered reasonable for NHS employees to have engaged in before now. For example, carework that takes the form of a commitment to 'staying with, in spite of', has come to the fore in images and testimonials depicting doctors and nurses remaining steadfast at their posts, 'heedless of their own health as they work tirelessly to care for people in the face of the Coronavirus pandemic'2. It

\footnotetext{
${ }^{2}$ The full quote from the website is: 'From cradle to grave, the National Health Service, and the incredible professionals within it who care for us, is a part of British life. Today, more than ever, we should cherish those who dedicate themselves to our care, 'heedless of own health as they work tirelessly to care for people in the face of the Coronavirus pandemic' (NHS Heroes, 2020).
} 
is not clear whether such practices - of staying to care for others, correspond to the experiences of frontline NHS employees as a multiplicity, or whether they are imposed from elsewhere, or a combination of both, but because NHS staff are seen to be working on behalf of others at their own risk, and often in a way that requires them to withstand the most concentrated and contagious parts of the pandemic over an indefinite length of time, those who stay in post, or return to posts they had previously left, appear to be choosing to exercise a form of altruistic endurance. Moore (2020) notices that in social media posted by NHS staff bearing the message, "we stay here for you - please stay home for us', the NHS assumes the form of 'a subject that waits for citizens in their time of need'. Coming in the midst of a crisis, the outward forms for this kind of 'extreme' carework - of duty, self-sacrifice and a commitment to 'staying with, in spite of' might be read as the signs of a new orientation to the present characterised by the 'making of promises'.

In Paul Ricoeur's hermeneutic philosophy of time, the promise describes the public act of putting myself under an obligation of doing something, for someone. It is 'the projection of a horizon of expectation' made possible through the inscription of dialogue onto the public space where historical responsibility for it can be assumed' (Ricoeur, 1990, p. 234). Nomatter how unbelievable or fleeting the experiences of living and working through the first days of the pandemic might turn out to be in the longer term, the making of a promise stakes a claim in the present, announcing and prolonging it. There is something not quite congruent however, about the promise implied by such messages as 'we stay here for you - please stay home for us'. When glimpsed from below the level of image and identification, practices of staying and of 'being here for you' need to be understood as coming after a much longer, drawn out time in which the normal working day has been organised around the assumption that care is something that can only be apprehended at the specular level of the organisation, and where time is reduced to being just one of the costs of its production. They hint at modes of care that have been inspired by affective investments in what is 'real' about care work during a pandemic - its resistance to appropriation as, just 'a task to be accomplished' (Dejours \&


kinds has, until now, tended to be seen as synchronic output; as happening all at once, with little attention to how a particular labour of care might evolve over time, or how a continued engagement with it might help to 'sustain interdependent worlds' (Bellacasa, 2012, p. 198), the appearance of an unconditional promise to 'stay here for you' is something of an anomaly, pushing in the opposite direction to the one that healthcare had been going in.

Unpredictable, prolonged and intermittent timeframes are to be expected in the NHS, particularly in relation to chronic, multiple or undiagnosable illness of the kind that now makes up most of its workload. It could be the continuation of an older

\footnotetext{
${ }^{3}$ For Dejours, 'to work is, first, to experience the real, that is to say, experience the breakdown of technical know-how' (2010, p. 170).
}

formulation of care as synchronic, that has made staying with the idea that the activity of care might still be worthwhile in and of itself, increasingly difficult to justify (Latimer, 2000). Though outwardly they may be focused on making more 'time for care' (NHS England, 2019), policy initiatives that have sought to curtail the patient's and the practitioner's experience of time passing have tended to result in many temporal practices of care being rendered as obsolete. This is not to say that discretional practices of offering more time to some patients are not one of the inevitable consequences of making the offer to care in the first place, or that they haven't always gone on and won't continue to do so. But nevertheless, the growing concern amongst clinicians over finding themselves unable to spend time on the things that matter most to themselves and their patients, has been met until now with a response that questions their ability ever to have really known what it was worth their while having cared about in the first place. As one NHS England consultant put it, "we wondered how health and care systems could design services that would improve peoples' lives, if the people running the system didn't understand what matters most?'.

Kathleen Stewart observes that 'there's a politics to being/ feeling connected (or not), to affective contagion, and to all the forms of attunement and attachment' (Stewart, 2007, p. 16). It changes the way we think about the politics of staying at the frontline of a pandemic, if we remember that many of the most experienced members of the NHS workforce, those who have stayed or returned, and who are still working on 'our' behalf, bring with them a decades long history of attachment to the institution in relation to the slow collapse of a former symbolic order ${ }^{4}$. This is an order they worked hard to delay the future collapse of, even though they might well have wished to be released from it. It is a situation that has proven to be unendurable for many, as the annual problem of how to fill all the vacancies in British general practice affirms. Each year, a steady stream of doctors under the age of fifty, have made the decision not to stay, not to carry on. More than just a feeling of exhaustion from overwork, by the time they have left, many of these people, described quite tragically in one study as the 'lost to the NHS' (Doran et al., 2016) have reached the point of feeling that they had in some way been locked out from the time when real care was taking place.

Superficially, I think it would be difficult to imagine a more complete reversal of the recent past than what we are seeing on this new frontline, where virtually everything that 'the NHS' does is seen as extremely valuable, heroic even, in its relation to a future that has yet to unfold. One of the most contagious forms of agency that a temporality of acute crisis seems to be able to offer us now, is a capacity to become so immersed in the doings of the present that nothing else seems to matter ${ }^{5}$.

\footnotetext{
4 'The institutional and linguistic network (the province of duties, roles and obligations) and the values of a given culture' (Dashtipour, 2014, p. 5)

5 The resulting tendency to see everything only in relation to the virus carries its own risks for those who are dependent on health and social care services at a time when their needs may have increased whilst the availability and integrity of care and support has been reduced overall. An example of this is the impact of the Coronavirus Bill on the integrity of existing legal safeguards for adults with care and support needs and their carers: https://www. nsun.org.uk/news/covid-19-the-coronavirus-bill
} 
In this respect, coronavirus appears to have achieved in hours, what the official long form strategies for 'releasing time' never could, which is to have forced the making of more time for care into the present. In fact, an orientation to this time - as care, has not so much been offered to the workforce as required of them, just as to a lesser extent, it has been required of everybody whose time is having to be lived out firmly in the present (in lockdown), so that others might have more time to live on.

As with the politics of any 'surge', the afterlife of this crisis and of all the time for care that has miraculously bubbled up around it, may depend on events that have yet to come to pass; where the surge 'might go, what happens, how it plays itself out and in whose hands' (Stewart, 2007, p. 15). As my own observations of general practice were cut short, I was one of those who couldn't stay to follow the energy, to see 'where it might go', but from what I did see of the frontline after the first shock, I would say that there is something very fragile and forgetful about the forms the ordinary is taking and what they have the power to release under the influence of crisis.

\section{Data availability}

Any insights are based only partly and tangentially on ethnographic observations of a clinical site. No results are included in the article which might be said to be based on the raw data collected during these observations.

\section{Author contributions}

Stephanie Davies is a Birkbeck $\mathrm{PhD}$ candidate based in the Department of Psychosocial Studies and part of the Wellcome Trust-funded Waiting Times research project. She was undertaking an ethnography of waiting in a London general practice at the time of coronavirus first making its appearance in the UK which has since been temporarily suspended. She has an MA in Rhetoric and is also a registered Social Worker who has worked in the NHS in community mental healthcare teams.

\section{Acknowledgements}

This paper was developed in collaboration with colleagues working on the Waiting Times research project (see waitingtimes. exeter.ac.uk).
Bellacasa MP: “Nothing Comes Without Its World': Thinking with Care'. The Sociological Review. 2012; 60(2): 197-216.

Publisher Full Text

Catty ]: Lockdown and adolescent mental health: reflections from a child and adolescent psychotherapist [version 1; peer review: 2 approved]. Wellcome Open Res. 2020

PubMed Abstract | Publisher Full Text| Free Full Text

Dashtipour P: 'Freedom through work: The psychosocial, affect and work'. In: Kenny, K. and Fotaki, M. The Psychosocial and Organization Studies: Affect at Work, Studies in the Psychosocial. Palgrave Macmillan UK. 2014.

Publisher Full Text

Dejours C: Subjectivity, work and action. In: Deranty, J.P., Petherbridge, D. Rundell, J. and Sinnerbrink, R. (eds.) Recognition, work, politics: New directions in French critical theory. Leiden: Brill. 2007.

Publisher Full Text

Dejours C, DerantyJP: 'The Centrality of Work'. Critical Horizons. 2010; 11(2): 167-180.

Publisher Full Text

Doran N, Fox F, Rodham K, et al.: Lost to the NHS: a mixed methods study of why GPs leave practice early in England. BrJ Gen Pract. (Accessed: 14 April
2020). 2016; 66(643): e128-e135.

PubMed Abstract | Publisher Full Text | Free Full Text

Hammer E: Philosophy and Temporality from Kant to Critical Theory. Cambridge: Cambridge University Press. 2011.

Reference Source

Latimer J: The Conduct of Care: Understanding Nursing Practice. Abingdon: Wiley-Blackwell. 2000.

Reference Source

Moore M: Historicising "containment and delay": COVID-19, the NHS and

high-risk patients. Wellcome Open Res. 2020.

PubMed Abstract | Publisher Full Text| Free Full Text

NHS England: Releasing time for care. (Accessed 8 April 2020). 2019.

Reference Source

NHS Heroes: Thanks a Million NHS [Online]. (Accessed: 13 April 2020). 2020. Reference Source

Ricoeur P: Time and Narrative. Blamey, K. and Pellauer, D. (translators).

Chicago: The University of Chicago Press. 1990; 3

Reference Source

Stewart K: Ordinary Affects. Durham: Duke University Press. 2007.

Publisher Full Text 


\section{Open Peer Review}

\section{Current Peer Review Status:}

\section{Version 2}

Reviewer Report 03 September 2020

https://doi.org/10.21956/wellcomeopenres.17867.r40249

(c) 2020 Bergstresser S. This is an open access peer review report distributed under the terms of the Creative Commons Attribution License, which permits unrestricted use, distribution, and reproduction in any medium, provided the original work is properly cited.

\section{Sara M. Bergstresser}

Columbia University, New York, NY, USA

You have successfully clarified the nature of your contribution. The detailed background of how the topic emerged by necessity is a valuable addition. Good work.

Competing Interests: No competing interests were disclosed.

Reviewer Expertise: Anthropology (cultural medical focus), Public Health, Epidemiology, Bioethics.

I confirm that I have read this submission and believe that I have an appropriate level of expertise to confirm that it is of an acceptable scientific standard.

\section{Version 1}

Reviewer Report 21 July 2020

https://doi.org/10.21956/wellcomeopenres.17508.r39377

(c) 2020 Bergstresser S. This is an open access peer review report distributed under the terms of the Creative Commons Attribution License, which permits unrestricted use, distribution, and reproduction in any medium, provided the original work is properly cited.

\section{Sara M. Bergstresser}

Columbia University, New York, NY, USA

This article topic is particularly timely and important for the current moment. The breakdown of ordinary, everyday routines is an under-examined aspect of how crises manifest in social and professional worlds. I think there is a great deal of promise here, but there is also room to 
improve the paper.

This article offers an interesting glimpse into the theoretical analysis that would be used to contextualize an ethnographic study. My main concern (as someone trained in ethnographic research) is that for an article defined as being based in part on ethnographic observations, there is very little detailed ethnographic description included; the note indicates that "No results are included in the article which might be said to be based on the raw data collected during these observations". It might be the case that there are practical limitations on what data can be divulged at this point in the study, but if that is the case, I would recommend reframing the article more clearly as a theoretical piece, which may still include the author's personal narrative as autoethnographic portions.

There are two distinct paths to improvement. First, it can better fulfill the promise of ethnographic research by including more ethnographic description and data. For example, it could include additional passages like the quote from the NHS England consultant on p. 4. Second, if the first option is not feasible, it could be reframed to clearly offer a primarily theoretical rather than an ethnographic reading of the topic. The instances of personal narrative and observations can be integrated in either case, and additional connection of the author's personal experiences to the theoretical discussion would be productive.

I recognize that ethnographic work often does not fit the assumptions of a quantitative statistical science framework, which is often seen as the default, and that this may be the limiting factor - i.e. that including data could expose the piece to field-inappropriate questions of reproducibility. I would hope that if this is the limiting factor, that those in charge of editorial oversight might find a way for ethnographic data to be discussed in a way that does not subject it to questions of quantitative reproducibility, as qualitative ethnography is an inherently different form of knowledge production.

Is the work clearly and accurately presented and does it cite the current literature? Partly

Is the study design appropriate and is the work technically sound? Partly

Are sufficient details of methods and analysis provided to allow replication by others? Partly

If applicable, is the statistical analysis and its interpretation appropriate? Not applicable

Are all the source data underlying the results available to ensure full reproducibility? No source data required

Are the conclusions drawn adequately supported by the results? Yes

Competing Interests: No competing interests were disclosed. 
Reviewer Expertise: Anthropology (cultural medical focus), Public Health, Epidemiology, Bioethics.

\section{I confirm that I have read this submission and believe that I have an appropriate level of expertise to confirm that it is of an acceptable scientific standard, however I have significant reservations, as outlined above.}

\section{Author Response 20 Aug 2020}

Stephanie Davies, Birkbeck University of London, London, UK

Thank you very much for your review of my article. Your comments were gratefully received and read by me.

I do understand your reservations over my inclusion of the term 'ethnographic' in the paper which as you correctly point out, is primarily theoretical in its orientation. In response to your suggestion for either clarifying the theoretical nature of the work, or else adding in more material to support its claim to be ethnographic, I have included some statements which I hope will emphasise that this is intended as a theoretical rather than as an ethnographic article. They include a description of the work in the abstract as a 'short theoretical paper' where I specify that it was written immediately following the suspension of my original ethnographic investigation of waiting in general practice. This is in addition to the note at the end stating that any insights referred to in the work are based only partly and tangentially on ethnographic observations. I've also added a paragraph providing an outline of my original ethnographic study which I hope will help to draw a distinction in the reader's mind between the different pieces of work.

Competing Interests: No competing interests were disclosed.

Reviewer Report 11 June 2020

https://doi.org/10.21956/wellcomeopenres.17508.r39039

(c) 2020 Greenhalgh T. This is an open access peer review report distributed under the terms of the Creative Commons Attribution License, which permits unrestricted use, distribution, and reproduction in any medium, provided the original work is properly cited.

\section{Trish Greenhalgh}

Department of Primary Care Health Sciences, University of Oxford, Oxford, UK

I didn't know about the 'Waiting in Pandemic Times' project until I was invited to review this paper. So it was a bit of a treat to find a reflexive, theory-rich essay (I'm a dual qualified researcher in both medicine and social sciences, and have been peer-reviewing about one paper per day since March, all of them fast-tracked clinical papers on diagnostic tests, treatments etc).

So I liked the idea. 
I also liked the essay, broadly. It conveys very well the impact COVID-19 had on general practice the abrupt disruption of structured normality, with a particular focus on temporal structuring. Love the Ricoeur.

How to make it better?

Firstly, it lacks a sense of audience. Who are you writing for? As an academic clinician whose time has been disrupted since early March (no days off, no evenings off, just work work work to try to fight the fire), I didn't feel like you were speaking TO me, more that you were speaking ABOUT me. I felt I didn't have time to slow down and do a close read of your paper - partly because it was an unnecessarily hard read (one sentence at least went on for 17 lines!). This could be easily addressed by writing in shorter, clearer sentences (see Annemarie Mol as an example of someone who conveys complex philosophical concepts in prose that is delightfully easy to follow). More than ever, sociologists and humanities people who seek to enlighten and enrich the worlds of clinicians need to put work into making their writing accessible. (and I write as someone with a foot in both camps!)

Related to that point, and on the assumption that you do want to 'speak to' a healthcare audience, I strongly suggest you introduce some of your philosophical friends to that audience. Tell us just a bit about what Ricoeur said about time. It is clear to you (and I myself dimly remember) that Ricoeur placed great emphasis on the fact that we live in time and in history. Your observations about the disruption of time as the first COVID case appeared in GP land would be so much more powerful if you had brought the reader into Ricoeur's world with a brief intro. Likewise for the other greats you briefly refer to.

At the beginning I'd like to know more about this waiting project. Before COVID messed it up, what aspect of waiting were you studying? A paragraph with some ethnographic reflections on that study would convey what was canonical about general practice, making your subsequent description of disruption more powerful.

I wonder, too, whether you might return to that description of the canonical at the end of your essay and consider how far that has been lost forever (or for the foreseeable future)?

Hope these comments help, and thanks for taking me into a fascinating set of reflections.

Is the work clearly and accurately presented and does it cite the current literature? Partly

Is the study design appropriate and is the work technically sound? Partly

Are sufficient details of methods and analysis provided to allow replication by others? Partly

If applicable, is the statistical analysis and its interpretation appropriate? Not applicable

Are all the source data underlying the results available to ensure full reproducibility? 
No source data required

Are the conclusions drawn adequately supported by the results?

Yes

Competing Interests: No competing interests were disclosed.

Reviewer Expertise: GP, social scientist.

I confirm that I have read this submission and believe that I have an appropriate level of expertise to confirm that it is of an acceptable scientific standard. 